\title{
Effect of Seed Priming on Radish with Different Nutrients at Various Soaking Durations
}

\author{
Bilal Pervaiz Khan ${ }^{1}$, Neelam Ara ${ }^{1}$, Shujaat Ali ${ }^{1,2 *}$, Kamran Khurshid Baigh ${ }^{1}$ and Abdul Wahab
}

${ }^{1}$ Department of Horticulture, Faculty of Crop Production Sciences; The University of Agriculture Peshawar, Khyber Pakhtunkhwa, Pakistan; ${ }^{2}$ Department of Agricultural Sciences, University of Haripur, Khyber Pakhtunkhwa, Pakistan.

\begin{abstract}
The study was conducted at Agriculture Research Station Baffa Mansehra (ARSBM), Khyber Pukhtunkhwa in winter 2016, from the behalf of Agriculture University Peshawar, on the influence of priming of seed on radish cv. Green Neck with various nutrient sources; water and $1 \%$ of P solution of DAP, SSP, $1 \%$ $\mathrm{K}$ solution of $\mathrm{KCl}$ and $0.01 \% \mathrm{~B}$ solution of boric acid at different priming durations with 6 hours interval $(06,12,18,24$ hours). Un-soaked dried seeds were used as control. Research comprised of two factors i.e. sources and priming durations. There were 25 treatments having three replications. Priming seed significantly affected the germination and vegetative attributes of radish. The result of experiment showed that the highest germination percentage (86.4\%), percentage of survival (83.6\%), minimum days to emergence (9.1), tallest plant height $(41 \mathrm{~cm})$, yield of leaves plant ${ }^{-1}(14.4)$, leaf area $\left(295.8 \mathrm{~cm}^{2}\right)$, root length $(20.6 \mathrm{~cm})$, root weight in $\mathrm{g}$ (522.4) root diameter in $\mathrm{cm}$ (4.51), and total yield (23.8 tones ha $\mathrm{h}^{-1}$ ) were obtained when seeds were soaked in DAP solution. In case of storage duration, The maximum germination percentage (82.5\%), survival percentage $(84.4 \%)$, plant height $(43.7 \mathrm{~cm})$, ), total yield of leaves plant ${ }^{-1}(14.2 \mathrm{~g})$, area of leaf $\left(293 \mathrm{~cm}^{2}\right)$, root diameter $(4.50 \mathrm{~cm})$, root length $(20 \mathrm{~cm})$, root weight $(524.7 \mathrm{~g})$ and total yield ha ${ }^{-1}\left(23.9\right.$ tonesha $\left.^{-1}\right)$ were observed when seeds were primed for 18 hours priming duration in Di-ammonium phosphate DAP solution. Incase DAP, showed excellent performance in germination, growth and yield. While $\mathrm{KCl}$ also gave better results in most of parameters.

Received | January 29, 2020; Accepted | December 21, 2020; Published | February 15, 2021

*Correspondence | Shujaat Ali, Department of Horticulture, Faculty of Crop Production Sciences; The University of Agriculture Peshawar, Khyber Pakhtunkhwa, Pakistan; Email: shujat.swati@gmail.com

Citation | Khan, B.P., N. Ara, S. Ali, K.K. Baigh and A. Wahab. 2021. Effect of seed priming on radish with different nutrients at various soaking durations. Pakistan Journal of Agricultural Research, 34(1): 77-84.

DOI | http://dx.doi.org/10.17582/journal.pjar/2021/34.1.77.84

Keywords | Field experiment, Growth and yield, Nutrient sources, Priming durations, Priming of seed
\end{abstract}

\section{Introduction}

$\mathrm{R}^{2}$ adish (Raphanus sativus L.) belongs to Brassicaceae family, it is a cool season crop which grows best in autumn and spring all over the world. Radish is an important root vegetable. It is originated probably in indo-Pakistan subcontinent and western and central China (Bakhsh et al., 2006). In Pakistan, area under the cultivation for radish is 9,769 hectares and total yield was 160,265 tons, whereas in Khyber Pukhtunkhwa, there was 1,038 hectares total area for radish cultivation and yield was 12,858 tones (MNSF, 2015).

The radish is famous vegetable grown in both tropical and temperate regions. Radish are annual as well as biennial, but if the soil temperature is below $13^{\circ} \mathrm{C}$, the germination percentage fastly declines. When the crop grows and get established at average temperature $\left(10^{\circ} \mathrm{C}-18^{\circ} \mathrm{C}\right)$ and small day length so the best quality, size and shape of radish root can be obtained (Bodson et al., 2000). Radish can be cultivated on all types of 
soils. Sandy and sandy-loam soils are perfect, and permit fast production (Rathod et al., 2011) by the cultural practices, the yield of radish is influenced. The growth, production and development of radish are also affected by maximum plant density (Pervez et al., 2004). The fertilization is essential for the production of high quality radish. The major nutrients which are necessary by the plants for their growth and improvement are nitrogen, phosphorus and potassium (Singh et al., 2010).

Radish is cultivated for its tender fresh tuberous root which is used both cooked and fresh in salad (Shirani and Seran, 2009). It avoids constipation and has a cooling effect on human stomach (Torri and Hollenberg, 2012). Radishes are good for patients who are suffering from piles, liver problems and jaundice. In medical field, it is used for treatments of respiratory illnesses and liver disorders, it consists of mainly vitamins, sugar, protein and other important nutrients (Jaradat, 2005). The leaves are cooked as a greens which are famous for rich source of minerals and vitamins $\mathrm{A}$ and $\mathrm{C}$ (Haq et al., 2012).

Phosphorus is an important nutrient for the catalysis of numerous basic biochemical processes of plant (Wang, 2000). Phosphorus has the ability of taking and transforming the energy of sun into valuable compound of plant (Quiquampoix amd Mousain, 2005). During the fast growth period, Phosphorus is needed by plants and is also structural constituent of nucleic acid (DNA and RNA) and ATP (Plaxton and Tran, 2011). It is connected with root vigor and root development, rises resistance to root-rot, increases fruit quality, produces resistance against disease, encourages growth and provides early maturity (Deng et al., 2004). In plants, total $\mathrm{P}$ ranges from $0.05 \%$ to $0.50 \%$, when seeds are soaked in phosphorus, it gives a nutritious atmosphere to germinating embryo facilitating nutrient provision for development of crop (Lutts et al., 2016).

Some of the metabolic processes are activated by the priming that are essential for occurrence of germination before the real germination to get start (Yari et al., 2011). The syntheses of a few enzymes get activated in by priming that catalyze the mobilization of storage assets in radish seeds, while hydrolase activities weaken the endosperm (Noreen and Ashraf, 2009). Moreover, the production of antioxidants like peroxides, catalase and superoxide dismutase are increased by priming that helps in protecting the cell against membrane injury because of lipid peroxidation. Similarly, in primed seed adenosine triphosphate (ATP) production also increases (Gallardo et al., 2001). Abiotic stresses enhanced tolerance by priming, and raises the act of late sown wheat by developing chilling tolerance (Hussain et al., 2013).

Considering the above facts, the current research work was conducted with these objectives: To assess impact of priming of seed for germination and yield of radish and identify the best seed priming nutrients source and priming duration for radish, also determine the interaction impact of nutrients sources with priming duration.

\section{Methods and Materials}

The experiment effect of seed priming on radish with different nutrients sources at various soaking durations was carried out at Agriculture Research Station Baffa, Mansehra (ARSBM) during winter, 2016.

\section{Soil analysis}

During the experimental field random soil sample were taken, at the depth of $25 \mathrm{~cm}$ by the guage auger. The field soil was analyzed in the laboratory of soil science for chemical characteristics before sowing date at Baffa Agriculture Research station Mansehra (Table 1).

Table 1: Chemical and physical analysis of field soil at depth $25 \mathrm{~cm}$.

$\begin{array}{ll}\text { Determination } & \text { Quantity } \\ \text { Nitrogen (\%) } & 0.042 \\ \text { Phosphorus }\left(\mathrm{mg} \mathrm{kg}^{-1}\right) & 9.00 \\ \text { Organic matter }(\%) & 0.83 \\ \text { Potassium }\left(\mathrm{mg} \mathrm{kg}^{-1}\right) & 110 \\ \text { Texture class } & \text { Clay loam } \\ \mathrm{pH} & 7.3\end{array}$

\section{Field preparation}

Before the seeds were sown the land was perfectly prepared and all the stones, pebbles, weeds and the waste of the previous crops were removed. Leveling of the land was done to make sure that the supply of water could be uniform and adequate. Then the land was divided according to the experimental layout into the experimental units. 
Horticultural practices

All the cultural practices were uniformly performed i.e. hoeing, weeding and irrigation.

Method for solution preparation: The research comprised on two types of priming (hydro priming and nutrient priming). The solutions of various concentrations of different nutrients for priming were separately prepared in one liter of water.

Hydro priming: For hydro priming the seeds were soaked individually in $250 \mathrm{ml}$ of water in a jar.

Nutrient priming: Solutions of $\mathrm{Di}$ ammonium phosphate and single super phosphate at $1 \% \mathrm{P}$ concentrations were prepared. Solution of $\mathrm{KC} 1$, at $1 \%$ potassium concentration and that of boric acid at $0.01 \%$ boron concentration were made. For this purpose, $126.5 \mathrm{~g}$ of SSP, $149.5 \mathrm{~g}$ of DAP, $30.12 \mathrm{~g}$ of $\mathrm{KCl}, 1 \mathrm{~g}$ of $\mathrm{H}_{3} \mathrm{BO}_{3}$ were mixed in 1 liter of $\mathrm{H}_{2} \mathrm{O}$ to prepare these solution according to treatment concentration. The seeds were removed from those solutions after soaking for specified duration, then the seeds were air dried at room temperature for 30 minutes and then those seeds were sown in the experimental field.

\section{Design of experiment}

The research was performed in Randomized Complete Block Design (RCBD) having two factors. There were 25 treatments and each was replicated three times. The nutrient sources comprised factor one and soaking duration was second factor.

Factor A: nutrient sources; Water; Di ammonium phosphate (DAP) solution (1\% of P); Single super phosphate (SSP) solution (1\% of $\mathrm{P})$; Potassium chloride $(\mathrm{KCl})(1 \%$ of $\mathrm{K})$; Boric acid $\left(\mathrm{H}_{3} \mathrm{BO}_{3}\right)(0.01 \%$ of B)

Factor B: Soaking durations; Unsoaked (control); 6 $\mathrm{hr}, 12 \mathrm{hr}, 18 \mathrm{hr}, 24 \mathrm{hr}$.

\section{Seed sorwing}

All the treated seeds of radish cultivar were sown on the ridge. Two seeds were sown $1.5 \mathrm{~cm}$ deep in the soil while plant to plant distance was $25 \mathrm{~cm}$ and row to row distance $60 \mathrm{~cm}$. Soil around the seeds was pressed roughly. Thinning was done after the emergence of seedling to maintain one plant.
Parameters

The data on different parameters of field experiment were investigated as mentioned below.

Percent germination: Percent germination was based on the collected data for total number of germinated seeds divided by total number of sown seeds in the subplot.

The percent germination was found out by the given formula:

Percent germination $=\frac{\text { Total number of seeds germinated }}{\text { Number of total seeds }} \times 100$

\section{Survival percentage}

For this parameter, the data were obtained by determining total number of plants survived out of the number of total germinated plants.

By the given formula the survival percentage was found out:

Survival percentage $=\frac{\text { Total number of survived plants }}{\text { Total number of germinated plants }} \times 100$

\section{Days to emergence}

The data for days to emergence were collected from the date of sowing until the total number of days to emergence and their mean was computed.

\section{Plant height $(\mathrm{cm})$}

The plant height is taken from selected plants in each treatment was measured with meter rod from the tip to bottom of plant, when the plants gained its maximum size. In each treatment the height of plant was measured and their mean was obtained.

\section{Number of leaves plant ${ }^{-1}$}

Twelve plants were chosen randomly for all treatments in each replication and number of leaves per plant were counted and the average data was found out.

\section{Leaf area $\left(\mathrm{cm}^{2}\right)$}

In randomly selected plants of each plot, leaf area was measured with graph paper, while their means were calculated.

\section{Root length (cm)}

The soil was removed from the up rooted plants while each treatment incase of each replication was washed with tap water. The root length of twelve plants taken 
randomly and measured with the help tap and their mean was noted.

\section{Diameter of root $(\mathrm{cm})$}

The diameter of the root was measured by selecting twelve different plants using vernier caliper and was measured at three different points of radish and their mean was obtained.

\section{Weight of root (g)}

The root was detached from the stem and their weight was measured with digital balance for each plot.

\section{Yield (tones $h a^{-1}$ )}

The harvested roots were weighed in kilogram with the help of digital balance (DB) and were measured to find out the yield $\left(\mathrm{t} \mathrm{ha}^{-1}\right)$ through using the following formula for each treatment.

Yield $\mathrm{ha}^{-1}=\frac{\text { Yield per sub polt }(\mathrm{Kg})}{\text { Area of sub plot }\left(\mathrm{m}^{2}\right) \times 1000} \times 10000 \mathrm{~m}^{2}$

\section{Statistical analysis}

Statistical analysis of data was done through Statistic 8.1 software. While, the mean treatments were evaluated by least significant difference (LSD) test ( $P$ $=0.01)($ Steel et al., 1980).

\section{Results and Discussion}

\section{Growth behavior}

The related data regarding with yield and growth characteristics indicated that priming methods in various nutrients solutions and different soaking duration remained statistically significant $\left(\mathrm{P}_{\leq} \leq .01 \%\right)$ on percent germination, total number of days to emergence, percentage of survival, plant height, number of leaves plant ${ }^{-1}$, leaf area $\left(\mathrm{cm}^{2}\right)$, length of roots $(\mathrm{cm})$, diameter of roots $(\mathrm{cm})$, weight of roots (g), yield $\left(\right.$ tonesh $\left.^{-1}\right)$.

Germination percentage showed significant differences to priming sources and storage duration. Highest plant germination percentage was recorded (86.4 \%) when seed of radish primed in DAP solution, followed by (81.9\%) when seed soaked $\mathrm{KCl}$ solution. While least germination percentage was noted $(72.0 \%)$ while seeds soaked in water. Among the soaking durations of radish seeds. Maximum days to germination percentage $(82.5 \%)$ were observed when seed primed for 18 hours, followed by 24 hours germination percentage $(81.2 \%)$. While minimum germination percentage $(68.7 \mathrm{~cm})$ was found in control treatment.

The studied results about different sources showed that minimum days to emergence (9.10) were observed in seeds which were primed in $\mathrm{Di}$-ammonium phosphate (DAP) solution, which followed by days to emergence (10.2) in $\mathrm{KCl}$ primed seeds, while the increasing trend days to emergence (12.70) were noted in untreated seeds. Among the soaking durations, minimum days to emergence (10.1) was recorded in seeds primed for 18 hours, which followed by (10.5) seeds soaked for 12 hours, while the maximum trend days to emergence (12.7) was recorded in control treatment.

Similarly, the means values of different sources revealed maximum survival is $(83.6 \mathrm{~A} \%)$ was obtained when seeds were primed in DAP solution, which statistically at par with seeds primed with $\mathrm{KCl}$ having survival percentage noted up to $82.20 \%$, while the least survival percentage (74.3\%) was noted in plants of seeds which were kept un- soaked. In case of storage duration, the highest survival (84.4\%) obtained after 18 hours of primed seeds, followed by 24 hours survival (83 \%). While least survival (71.3\%) was recoded at zero storage.

The plant height was increased and the vegetative growth was satisfactory with early emergence and good establishment of plants. The leaves and branches produced positive competition for light, nutrients and water which resulted in supplementary growth of plants. According to means values of plant height. Highest plant height $(41.1 \mathrm{~cm})$ and $(38.9 \mathrm{~cm})$ was found with seed primed by $\mathrm{DAP}, \mathrm{KCl}$ solutions. Whereas, minimum plant height $(32.2 \mathrm{~cm})$ and $(34.4 \mathrm{~cm})$ were obtained with seed primed by water, $\mathrm{H}_{3} \mathrm{BO}_{3}$. In case of storage duration, maximum plant height $(43.7 \mathrm{~cm})$ and $(42.3 \mathrm{~cm})$ after $18-24$ hours. Whereas, least plant height $(26.1 \mathrm{~cm})$ affected by control treatment.

Similarly, Mean values of number of leaves about different sources showed, maximum number of leaves $(14.4 \mathrm{~cm})$ was obtained with seed primed in DAP, followed by $\mathrm{KCl}$ primed seed $(13.3 \mathrm{~cm})$, while the minimum number of leaves $(12.4 \mathrm{~cm})$ was recorded in unprimed seeds. Among the soaking durations, maximum number of leaves $(14.2 \mathrm{~cm})$ was obtained in seeds primed for $18 \mathrm{~h}$, traced by seeds $(13.6 \mathrm{~cm})$ 
soaked for $24 \mathrm{~h}$, while the least number of leaves (11.6 $\mathrm{cm}$ ) was recorded in control plots.

Data of different sources indicated that maximum leaf area was found in plants of seeds $\left(295.8 \mathrm{~cm}^{2}\right)$ which were primed in DAP solution, traced by leaf area $\left(291.9 \mathrm{~cm}^{2}\right)$ in $\mathrm{KCl}$ primed seeds, while the minimum leaf area $\left(283.0 \mathrm{~cm}^{2}\right)$ was recorded in untreated seeds. Among the soaking durations, maximum leaf area $\left(293 . \mathrm{cm}^{2}\right)$ was observed in seeds primed for $18 \mathrm{~h}$, traced by $\left(291.5 \mathrm{~cm}^{2}\right)$ seeds soaked for $24 \mathrm{~h}$, while the least leaf area $\left(279.2 \mathrm{~cm}^{2}\right)$ was recorded in control plots.

Likewise, the highest root diameter $(4.51 \mathrm{~cm})$ was obtained when seeds were primed in DAP solution. Which statistically at par with seeds primed with $\mathrm{KCl}$ having root diameter $(4.43 \mathrm{~cm})$. Whereas, minimum root diameter $(3.75 \mathrm{~cm})$ was recorded in plants of seeds which were kept un- soaked. In case of soaking durations, highest root diameter $(4.52 \mathrm{~cm}, 4.37 \mathrm{~cm})$ were obtained with seed primed for $18 \mathrm{~h}-24$. While least root diameter $(3.63 \mathrm{~cm})$ was obtained in control treatment.

The studied results indicated that maximum diameter might be due to vigorous vegetative growth and earlier germination and also due to adequate absorbance of nutrients in initial phase of emergence. These results are also supportive by Espanany et al. (2016) who reported that the rapid increase in diameter might be due to early emergence and vigorous vegetative growth. Shah et al. (2011) also recorded maximum stem diameter in primed seeds plants as compared to unprimed seeds plants.

The mean values of root length indicated that the maximum root length $(20.6 \mathrm{~cm})$ was found when seeds were primed in DAP solution, followed by $(19.1 \mathrm{~cm})$ with seed primed $\mathrm{KCl}$ solution. While largest root length $(16.4 \mathrm{~cm})$ was documented in control treatment. Similarly, significant differences were recorded in soaking storage duration. The highest root length $(20.0 \mathrm{~cm}, 18.9)$ were noted with seeds leaved for $18 \mathrm{~h}$ and $12 \mathrm{~h}$ in different soaking sources. While least root length was recorded in un-soaked seeds.

The mean values of root weight showed significant differences (Table 1). The maximum root weight $(522.4 \mathrm{~g})$ was obtained when seeds were primed in DAP solution. This treatment was followed by seeds primed with $\mathrm{KCl}$ having root weight $(516.9 \mathrm{~g})$. At while the minimum root weight (495.1g) was recorded in plants of seeds which were kept soaked in water. In case of storage duration, the highest root weight $(23.9 \mathrm{~g})$ was noted when seeds were for $18 \mathrm{~h}$, which statistically at par one another when seed primed with for $24 \mathrm{~h}$ gives $(23.5 \mathrm{~g})$ root weight. While least root weight was recorded in un-soaked treatment.

Similarly, higher yield tons/ha (23.8) was observed when seeds soaked with DAP followed by seeds primed with $\mathrm{KCl}$ (23.5 tons $\mathrm{ha}^{-1}$ ). Whereas, the decreasing trend yield tons/ha (22.5) was investigated in plants of seeds were soaked in water. Storage duration also showed significant differences yield tons/ha. Maximum yield tons/ha $(23.9,23.5)$ were obtained after $18 \mathrm{~h}, 12 \mathrm{~h}$ days of storage duration. Whereas, least yield tons/ha was noted in control treatment.

The increase in germination percentage by soaking might be due to the fact that it initiates some seed biochemical reactions which are essential to start the early process of germination, activates the enzymes and break the dormancy of hard seed coat, decrease the activities of hydrolysis and growth retardants (Mehta et al., 2014). Bittencourt et al. (2005) who claimed that seed priming in asparagus resulted in high germination percentage than control treatment. Days to emergence was considerably reduced when seeds were primed in nutrients solution as compared to unprimed seed (Baig et al., 2020). For the establishment of good crops, emergence is a necessary process. For regular emergence, nutrients, oxygen, temperature, sufficient amount of water, viability of seeds and good quality of soil are required. The results of research are parallel with the findings of (Saleem et al., 2014) who reported the least days to emergence in various crop. In primed seeds of various crop these result is also in agreement with work of (Shah et al., 2011) who claimed that primed seed of okra in $1 \%$ single super phosphate solution for $24 \mathrm{~h}$ condensed time of emergence. Harris et al. (2001) reported that the pathogens act as germination inhibitor when the seed are sown in the soil and damage the young seedlings that inhibit the percentage of germination and as a result the seedlings are not capable to survive more. Therefore, the resultant seedlings are weak, which cannot further survive and are more liable to pest attack and disease. Musa et al. (2001) who recognized seed priming as more challenging to pest 
and disease attack because the seedlings got stronger as compared to untreated seeds. Shah et al. (2011) Observed that the survival of majority of plants was recorded when seeds of okra was primed in single super phosphate solution for 24 hours. Soughir et al. (2013) investigated that highest plant height was measured in primed seed while the unprimed seeds results showed lowest plant height. The plant height was increased and the vegetative growth was satisfactory with early emergence and good establishment of plants. Alam et al. (2013) documented that leaves and branches produced positive competition for light, nutrients and water which resulted in supplementary growth of plants. These results findings by Soughir et al. (2013) who noted that priming of seed techniques enhanced crop stands than control. Raturi (2013) also reported that when the seed of cucumber and brinjal were primed in $\mathrm{KH}_{2} \mathrm{PO}_{4}$ and $\mathrm{Na}_{2} \mathrm{HPO}_{4}$ solutions, they gave maximum number of leaves. Singh et al. (2015) also observed that $\mathrm{P}$ seed priming in spinach and maize, respectively, improved leaf area. Our findings confirm those of Soughir et al. (2013) who notified that seed priming enhanced crop establishment. Yoon et al. (1994) noted that more primary branches, total number of leaves, plant height, leaf area were formed when seeds of cucumber were dipped in primed solution of $\mathrm{KH}_{2} \mathrm{PO}_{4}$ and $\mathrm{Na}_{2} \mathrm{HPO}_{4}$, Similarly Lutts et al. (2016) also documented that maximum plants were produced when seed were primed in the solution of essential nutrients as compared to un-primed seeds in brinjal crop. The root length is the main quality attribute, which is relevant to the consumer preference for long radishes. Meena et al. (2017) recorded that length of fruit, weight of fruit and plant yield are vital parameters that are related to yield of fruit ha ${ }^{-1}$, which were obtained highest in $\mathrm{GA}_{3}$ primed seed plants than control plants. Baig et al. (2020) who recognized that in seed priming in $1 \%$ single super phosphate solution for $24 \mathrm{~h}$ not only improved vegetative and germination characters but also enhanced the yield related parameters, like length of the fruit and weight of the fruit. In the current study, it was investigated that the root weight was showed increasing by seed priming in DAP solution. These outcomes also confirm results of Ghassemi and Esmaeilpour (2008) who noticed quick germination and seedling establishment that resulted in healthier growth of plants, which eventually raised fruit weight. Sufficient amount of phosphorus probably resulted in high DNA and ATP production and therefore may have stimulated the anti- oxidative and metabolic activities. The present results are also confirmed by Miraj (2012) who documented that the okra seeds were primed with 1\% SSP solution for the duration of $24 \mathrm{~h}$ resulted in higher pod yield of $5063.53 \mathrm{~kg} \mathrm{ha}$ ${ }^{1}$, whereas less $1507 \mathrm{~kg} \mathrm{ha}^{-1}$ pod yield was obtained in untreated seeds.

\section{Conclusions and Recommendations}

Seed priming techniques proved best to solve the problem of poor germination, late emergence and less plants survival after emergence. Emergence of seeds, percent survival, total number of leaves, root weight, plant height, diameter of root and finally total yield (tons/ha) of radish were successfully improved by seed priming in DAP $1 \%$ solution for 18 hours duration. Therefore 18 hours soaking duration best to germination characteristics of seeds and other growth and yield attributes of radish crop.

\section{Acknowledgements}

The authors are grateful to Agriculture Research Station Baffa Mansehra (ARSBM). Which helped in conducting this project from the behalf of Agriculture University of Peshawar, Pakistan. I highly appreciate and acknowledge the effort made by Supervisor $\mathrm{N}$ Ara and co-Authors and substantial contribution to accomplish this study.

\section{Novelty Statement}

The current research study was under taken to evaluate the influence of seed priming on germination and yield of radish.

\section{Author's Contribution}

Neelam Ara: Supervised the research work.

Bilal Pervaiz Khan: Designed and performed the experiment.

Shujaat Ali: corresponding author, wrote the paper according the journal format.

The rest of co-Authors review the analyzed data.

\section{Conflict of interest}

The authors have declared no conflict of interest.

\section{References}

Alam A., N. Amin, N. Ara, M. Ali and I. Ali. 
2013. Effect of various sources and durations of priming on spinach seeds. Pak. J. Bot., 45(3): 773-777.

Baig K.K., N. Ara, S. Ali, B.P. Khan, A. Wahab and U. Rabbani. 2020. Effect of seed priming on bitter gourd with different sources of phosphorus at various soaking durations. Pure Appl. Biol., 9(1): 80-90. https://doi. org/10.19045/bspab.2020.90010

Bakhsh, K., B. Ahmad, Z.A. Gill and S. Hassan. 2006. Estimating indicators of higher yield in radish cultivation. Int. J. Agric. Biol., 8(6): 783787.

Bittencourt, M.L.d.C., D.C.F.d.S. Dias, L.A.d.S. Dias and E.F. Araújo. 2005. Germination and vigour of primed asparagus seeds. Sci. Agric., 62(4): 319-324. https://doi.org/10.1590/ S0103-90162005000400003

Bodson, S.R., S.G. Bharad, V.M.S.V. Dod and Gholap. 2000. Effect of $\mathrm{N}$ and $\mathrm{P}$ on growth and yield of radish. Drissa. J. Hortic., 26(2): 34-36.

Deng, Z., B.K. Harbaugh, R. Kelly, T. Seijo and R.J. McGovern. 2004. Evaluation of caladium cultivars for resistance to pythium root rot. Hortic. Sci., 39(4): 772E-773. https://doi. org/10.21273/HORTSCI.39.4.772E

Espanany, A., S. Fallah and A. Tadayyon. 2016. Seed priming improves seed germination and reduces oxidative stress in black cumin (Nigella sativa) in presence of cadmium. Ind. Crops Prod., 79: 195-204. https://doi.org/10.1016/j. indcrop.2015.11.016

Gallardo,K.,C.Job,S.P.Groot,M.Puype,H.Demol, J. Vandekerckhove and D. Job. 2001. Proteomic analysis of Arabidopsis seed germination and priming. Plant Physiol., 126(2): 835-848. https://doi.org/10.1104/pp.126.2.835

Ghassemi, G.K and B. Esmaeilpour. 2008. The effect of salt priming on the performance of differentially matured cucumber (Cucumis sativus) seeds. Not. Bot. Horti Agrobo. ClujNapoca, 36(2): 67-70.

Harris, D., B. Raghuwanshi, J. Gangwar, S. Singh, K. Joshi, A. Rashid and P. Hollington. 2001. Participatory evaluation by farmers of on-farm seed priming in wheat in India, Nepal and Pakistan. Exp. Agric., 37(3): 403. https://doi. org/10.1017/S0014479701003106

Hussain, I., A. Riaz, M. Farooq and A. Wahid. 2013. Seed priming improves the performance of poor quality wheat seed. Int. J. Agric. Biol.,
15(6): 1560-8530.

Jaradat, N.A., 2005. Medical plants utilized in Palestinian folk medicine for treatment of diabetes mellitus and cardiac diseases. Al-Aqsa Univ. J. (Natl. Sci. Ser.), 9(1): 1-28.

Lutts, S., P.Benincasa, L.Wojtyla, S. Kubala, R.Pace, K. Lechowska, M. Quinet and M. Garnczarska. 2016. Seed priming: New comprehensive approaches for an old empirical technique. New challenges in seed biology-basic and translational research driving seed technology. pp. 1-46. https://doi.org/10.5772/64420

Meena, V.S., S.K. Meena, J.P. Verma, A. Kumar, A. Aeron, P.K. Mishra, J.K. Bisht, A. Pattanayak, M. Naveed and M. Dotaniya. 2017. Plant beneficial rhizospheric microorganism (PBRM) strategies to improve nutrients use efficiency: A review. Ecol. Eng., 107: 8-32. https://doi. org/10.1016/j.ecoleng.2017.06.058

Mehta, D., H. Kanwar, A. Thakur, S. Thakur and K. Thakur. 2014. Standardization of seed hydro-priming duration in bitter gourd, Momordica charantia 1. Int. J. Bio-resource Stress Manage., 5(1): 98-101. https://doi. org/10.5958/j.0976-4038.5.1.019

Miraj, G., 2012. Response of maize to phosphorus seed priming. The University of Agriculture, Peshawar Khyber Pakhtunkhwa, Pakistan.

MNSF, 2015. Fruit, vegetables and condiments statistics of Pakistan. Govt. of Pakistan, Ministry of Food and Agriculture (Economic wing) Islamabad. pp. 11-18.

Musa, A., D. Harris, C. Johansen and J. Kumar. 2001. Short duration chickpea to replace fallow after aman rice: The role of on-farm seed priming in the High Barind Tract of Bangladesh. Exp. Agric., 37(4): 509-521. https://doi.org/10.1017/S0014479701000448

Noreen, Z. and M. Ashraf. 2009. Changes in antioxidant enzymes and some key metabolites in some genetically diverse cultivars of radish (Raphanus satious L.). Environ. Exp. Bot., 67(2): 395-402. https://doi.org/10.1016/j. envexpbot.2009.05.011

Pervez, M., C. Ayub, B. Saleem, N.A. Virk and N. Mahmood. 2004. Effect of nitrogen levels and spacing on growth and yield of radish (Raphanus satious L.). Int. J. Agric. Biol., 6(3): 504-506.

Plaxton, W.C. and H.T. Tran. 2011. Metabolic adaptations of phosphate-starved plants. Plant Physiol., 156(3): 1006-1015. https://doi. 
org/10.1104/pp.111.175281

Quiquampoix,H.and D.Mousain.2005.Enzymatic hydrolysis of organic phosphorus. Organic phosphorus in the environment. pp. 89-112. https://doi.org/10.1079/9780851998220.0089

Rathod, P.H., J.C. Patel and A.J. Jhala. 2011. Potential of gamma irradiated sewage sludge as fertilizer in radish: evaluating heavy-metal accumulation in sandy loam soil. Commun. Soil Science Plant Anal., 42(3): 263-282. https:// doi.org/10.1080/00103624.2011.538880

Raturi, H.C., 2013. Studies on seed priming in cucumber (Cucumis sativus L.). Doctoral dissertation.

Saleem, M.S., M. Sajid, Z. Ahmed, S. Ahmed, N. Ahmed and S. Islam. 2014. Effect of seed soaking on seed germination and growth of bitter gourd cultivars. J. Agric. Vet. Sci., 6(6): 7-11. https://doi.org/10.9790/2380-0660711

Shah,A.R., N.Ara and G. Shafi.2011. Seed priming with phosphorus increased germination and yield of okra. Afr. J. Agric. Res., 6(16): 38593876.

Shirani, A. and T. Seran. 2009. Effect of foliar application of urea as top dressing on yield of radish (Raphanus sativus L.) in sandy regosol.

Singh, G., D. Biswas and T. Marwaha. 2010. Mobilization of potassium from waste mica by plant growth promoting rhizobacteria and its assimilation by maize (Zea mays) and wheat (Triticum aestivum L.): A hydroponics study under phytotron growth chamber. J. Plant Nutr., 33(8): 1236-1251. https://doi. org/10.1080/01904161003765760

Singh, H., R.K. Jassal, J. Kang, S. Sandhu, H. Kang and K. Grewal. 2015. Seed priming techniques in field crops-A review. Agric. Rev., 36(4): 251-
264. https://doi.org/10.18805/ag.v36i4.6662

Soughir, M., M. Elouaer and C. Hannachi. 2013. The effect of $\mathrm{NaCl}$ priming on emergence, growth and yield of fenugreek under saline conditions. Cercetari Agron. Moldova, 46(2): 73-83. https://doi.org/10.2478/v10298-0120085-7

Steel, R., J. Torrie and D. Dickey. 1980. Principles and procedures of statistics: A biometrical approach McGraw-Hill. New York.

Torri, M.C. and D. Hollenberg. 2012. Therapeutic uses of edible plants in Bangalore city, India: Combining health with cooking practices through home herbal gardens. Environ. Dev. Sustain., 14(3): 303-319. https://doi. org/10.1007/s10668-011-9324-6

Haq, U.Z., Y. Jamil, S. Irum, M.A. Randhawa, M. Iqbal and N. Amin. 2012. Enhancement in the germination, seedling growth and yield of radish (Raphanus sativus) using seed presowing magnetic field treatment. Polish J. Environ. Stud., 21(2): 369-374.

Wang, X., 2000. Multiple forms of phospholipase $\mathrm{D}$ in plants: The gene family, catalytic and regulatory properties, and cellular functions. Prog. Lipid Res., 39(2): 109-149. https://doi. org/10.1016/S0163-7827(00)00002-3

Yari, L., F. Khazaei, H. Sadeghi and S. Sheidaei. 2011. Effect of seed priming on grain yield and yield components of bread wheat (Triticum aestivum L.). J. Agric. Biol. Sci., 6(6): 1-5.

Yoon, B.-h., H.J. Lane and B.G. Cobb. 1994. 871 PB 223 improved germination of pansy seed at high temperatures by priming with salt solutions. HortScience, 29(5): 558e-558. https://doi. org/10.21273/HORTSCI.29.5.558e 